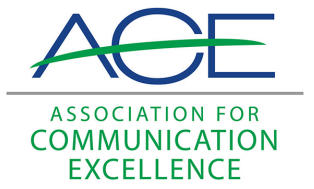

Journal of Applied Communications

\title{
Handbook of Nonsexist Writing for Writers, Editors and Speakers; Marketing to Women; Microcomputer Primer (First Edition): A Layman's Guide for Selection and Use of Microcomputers in Developing Countries
}

Dennis Hinkamp

Joe Courson

Jim King

Follow this and additional works at: https://newprairiepress.org/jac c) (1) (2) (-)

This work is licensed under a Creative Commons Attribution-Noncommercial-Share Alike 4.0 License.

\section{Recommended Citation}

Hinkamp, Dennis; Courson, Joe; and King, Jim (1985) "Handbook of Nonsexist Writing for Writers, Editors and Speakers; Marketing to Women ; Microcomputer Primer (First Edition): A Layman's Guide for Selection and Use of Microcomputers in Developing Countries," Journal of Applied Communications: Vol. 68: Iss. 1. https://doi.org/10.4148/1051-0834.1642

This Review is brought to you for free and open access by New Prairie Press. It has been accepted for inclusion in Journal of Applied Communications by an authorized administrator of New Prairie Press. For more information, please contact cads@k-state.edu. 


\title{
Handbook of Nonsexist Writing for Writers, Editors and Speakers; Marketing to Women ; Microcomputer Primer (First Edition): A Layman's Guide for Selection and Use of Microcomputers in Developing Countries
}

\author{
Abstract \\ Reviews of "The Handbook of Nonsexist Writing for Writers, Editors and Speakers by Casey Miller and \\ Kate Swift; "Marketing to Women," by Cecelia Reed, Mark Sullivan and Neal Hirschfeld; and \\ "Microcomputer Primer (First Edition): A Layman's Guide for Selection and Use of Microcomputers in \\ Developing Countries," by John L. Woods.
}




\section{Reviews}

"The Handbook of Nonsexist Writing for Writers, Editors and Speakers" by Casey Miller and Kate Swift; Harper and Row, Publishers, Inc. 10 East 53rd Street, New York, NY 10022.

People who have tried to research the topic of sexism quickly find themselves overwhelmed by material. Getting a succinct, readable description of what is and isn't sexist language is another story.

The Handbook of Nonsexist Writing is. in my opinion, comparable to Strunk and White's Elements of Style in its usefulness to the professional writer/journalist. It is well organized and gives concise, well-indexed, everyday examples of taking the sexism out of your writing.

Although it does spend some time on the philosophy behind the sexist nature of some terms, most of the information is presented in more of a stylebook manner. Even the most sexism-conscious writer should be able to find a few new helpful guidelines.

Specific chapters deal with avoiding the male-as-norm error, solving pronoun problems, parallel treatment of women and men, and alternatives to worn-out cliches.

At a trim 125 pages, for less than $\$ 5$, it would be an excellent addition to your desk or office reference collection.

Dennis Hinkamp

Utah State University

\footnotetext{
"Marketing to Women," by Cecelia Reed, Mark Sullivan and Neal Hirschfeld, Advertising Age, April 2, 1984, pp., M-9, M-22, M-26.
}

Advertisers and product marketers will base many of their decisions on a Special Report: Marketing To Women, published in ADVERTISING AGE.

The report gives good ideas for Extension professionals in developing and delivering programs for a female audience. 
- Women have fought-and continue to fight-long and hard for the right to be as successful-or as miserable or frustrated-as any man.

- They see themselves as part of a segment, but not a sexual one.

- A woman buys a product pretty much the same way a man does. You have to do advertising that appeals to both.

- Women base decisions on need, desire, and ability to pay.

The report points out shifting attitudes.

- Women have a renewed interest in expressing their femininity, as well as their concerns about health, safety, and nutrition.

- You will see femininity and romance as major themes.

- Women will begin to cook more at home in the coming years.

- Women are increasingly more interested in financial information.

- You will see more sampling (of products) to the point of some drug stores having an entire department that carries only sample size merchandise.

One story sums up the report: "It's no longer one big amorphous mass of working women."

Joe Courson

University of Georgia

"Microcomputer Primer (First Edition): A Layman's Guide for Selection and Use of Microcomputers in Developing Countries." John L. Woods. UNDP Asia and Pacific Programme for Development Training and Communication Planning. MRS. \#106. February, 1984.

As director of the UNDP Programme for Development Training and Communication Planning (DTCP), ACE member John Woods has had a long and varied experience working in developing countries.

In this paper, he builds upon that experience and DTCP background to introduce us to the use of microcomputersthe equipment, programs and their selection, buying guidelines, and getting started with micros. This is a practical guide with suggestions for all persons interested in microcomputer applications to their jobs. 
Some of the uses of micros are summarized first: typing letters and reports, financial and other calculations, statistical analysis, graphics, information storage and retrieval, mailing lists, project planning methods, training, and games.

In the equipment section, Woods describes the main types of equipment that may be needed in a micro system. That includes the processor, add-on cards, disk drive, screens, printers, and accessories. This is not a technical section; rather it is written in language a layman can understand. And it is full of practical suggestions that are direct and to the point: "For both letter quality and dot matrix printers, it is not wise to 'skimp' on cost. For office use it is best to buy the top-of-the-line printers as they are the most durable for heavy use, provide best quality, and have faster speeds."

Woods points out that the real success to using micros is in the software. He lists the programs available for ten application areas, ranging from word processing and spreadsheets to data base management. This section discusses user friendly programs and cautions those interested in micros to focus on learning applications of the commercially available programs, rather than spending time on learning a microcomputer programming language.

To cover the human element, the author details some considerations in deciding to purchase a micro. He highlights attitudes of the staff together with management attitudes. Maintenance factors also are mentioned. To decide what to buy, read his paper and talk to users everywhere. Prospective buyers can look to the dealer for information, and of course, to many magazines and books on both general computer usage as well as on specific machines and applications.

Once the computer is in place and the software loaded, how do you get started? First, be patient, Woods cautions. Use the dealer, make sure the machine and programs are maintained, provide training and time to learn, and, of course, make it fun.

This handy little document offers everyone a lot of suggestions and guidelines without preaching or selling. Woods is sensitive to the needs of communicators in developing countries, and it shows in this publication. 